\title{
Habsburg geopolitika
}

A. Wess Mitchell: A Habsburg Birodalom nagystratégiája. Budapest: Antall József Tudásközpont, 2020. 448 o.

https://doi.org/10.47707/Kulugyi_Szemle.2020.4.09

„Jelen könyv egyetlen kérdésfeltevésből született: hogyan képes egy véges erőforrásokkal rendelkező nagyhatalom egyszerre több ellenféllel is felvenni a harcot a stratégiai versenyfutás terén? Az erő demonstrálása minden államnál korlátokba ütközik; legtöbbjük pedig olyan fenyegetésekkel néz szembe, amelyek a megfelelő kombinációban nyilvánvalóan meghaladják önvédelmi képességüket. Bizonyos államok esetében azonban a fenyegetések messze meghaladják e képességet. A földrajzilag köztes helyzetben elhelyezkedő nagyhatalomnak - vagyis az olyan, erős katonai potenciállal rendelkező államnak, amely más hatalmi központok között helyezkedik el - egyszerre több irányból is számítani kell komoly fenyegetésekre. (...) Az ilyen állam kiszolgáltatottabb a geopolitikai zűrzavarnak, nehezebben tudja elkerülni a háborús kimerülést, s jobban függ a fenntartható biztonság érdekében kötött pénzügyi, emberi és morális kompromisszumoktól, mint azok az államok, amelyek nagyobb földrajzi védettséget élveznek" (Mitchell, 2020, 9. o.).

Wess Mitchellnek a Habsburg Birodalom nagystratégiájáról írott könyve nem szokványos történelmi elemzés. Könyvtárnyi irodalom született már a Habsburgok 1700 és 1866 közötti korszakáról. Azok az elemzések és könyvek főleg a történettudomány módszereivel éltek, Mitchell viszont - aki a saját bevallása szerint nem kívánt egy újabb történelmi elemzést írni, hanem a geopolitika szempontjából elemezte a Habsburg Birodalmat (Mitchell, 2020, 33. o.) - geopolitikai/geostratégiai oldalról vizsgálja azt. Ezzel azt a híres amerikai geopolitikai elemzői hagyományt folytatja, amelyet olyan nevek fémjeleznek, mint Henry Kissinger, Zbigniew Brzezinski vagy Brent Scowcroft. Mitchellnek az utóbbi időben publikált másik munkája (Grygiel és Mitchell, 2017) sokak szerint perdöntő hatással volt a 2017-ben kiadott amerikai nemzetbiztonsági stratégiára (Trump White House Archives, 2017). Mitchell az elméleti munkája mellett - Kissingerhez, Brzezinskihez és Scowcrofthoz hasonlóan - fontos szerepet játszott az amerikai kormányzatban is: 2017 októberétől 2019 februárjáig a külügyminisztérium Európáért felelős államtitkára volt, majd a NATO-reformért felelős munkacsoport egyik vezetője lett.

Mitchell vizsgálatának egyértelmú tárgya a "földrajzilag köztes helyzetben elhelyezkedő nagyhatalom". Szerinte a történelem során ilyen volt például a Perzsa Birodalom, a Bizánci Birodalom vagy a Lengyel-Litván Unió. Az ilyen jellegú birodalmak fennmaradása mindig történelmi kihívás volt. A szerző számára a Habsburg Birodalom is alapvetően ilyen „köztes birodalom” volt, hiszen északnyugaton szinte állandó konfliktusban 
állt Franciaországgal, északkeleten Poroszországgal, délen és keleten pedig az Oszmán, illetve az Orosz Birodalommal. Azt lehet mondani, hogy négy fronton is ütközött nála erősebb birodalmakkal. Mitchell azt is vizsgálta, hogy a Habsburg Birodalom a rá jellemző gyenge politikai egység ellenére miképp volt képes többé-kevésbé sikeresen túlélni e geopolitikai aknamezőn az 1700 és 1866 közötti időszakban.

1700-ban kihalt a Habsburgok spanyol ága, így a dunai ág elveszítette minden nyugati területét, és a birodalom központja keletre került. A spanyol örökösödési háborúban a Habsburgok többfrontos harcra kényszerültek: az olasz fronton spanyol-francia seregekkel találták szemben magukat, míg a németen bajor és francia csapatok nyomultak a seregeik ellen. Délen az oszmán erők, északon, Csehországban XII. Károly svéd seregei veszélyeztették a birodalmat. A határain belül pedig francia és török támogatással II. Rákóczi Ferenc kuruc serege lázadt Bécs ellen. A dunai birodalom mégis túlélte a létét fenyegető többfrontos háborút:

"A Habsburg Monarchia mégis újra és újra túlélt. ... Minden alkalommal dacolt a rá leső fenyegetésekkel, a harcokból pedig többször került ki a győztes, mint vesztes oldalon. Habár csatáinak javát elvesztette, a háborúk többségét megnyerte, s tovább gyarapította területét jóval az után, hogy hatalmát mindenki leírta. ... A Habsburg Birodalom gyakorlatilag bármely mértékkel nézve - élettartam, győztes csaták száma, fenntartott szövetségek száma vagy gyakorolt befolyás nagysága - geopolitikai sikertörténet" (Mitchell, 2020, 21. o.).

Felmerül a kérdés, hogy ez a geopolitikai sikertörténet vagy másképpen a Habsburgrejtély miképp alakulhatott ki. Az erre adott válaszában rugaszkodik el a szerző a legmesszebbre a történettudomány módszereitől. Mitchell helyesen ismeri fel, hogy annak ellenére, hogy a bécsi birodalom a területe és a lakossága alapján akár elsőrangú európai hatalom is lehetett volna, nemzeti sokszínűsége és kormányzásának hiányosságai - főleg a centralizáció lehetetlensége - miatt nem tudta elérni azt a fejlettségi szintet. E ténnyel Bécs uralkodói mindig is tisztában voltak, és ezért is volt hosszú ideig védekező a geopolitikai stratégiájuk. Egy viszonylag gyenge állam egy geopolitikai aknamezőn nem is vállalhatott fel más jellegű stratégiát. Mitchellnek valószínúleg igaza van abban, hogy azért nem írta meg eddig senki a Habsburgok geostratégiáját, mert az ilyen témájú könyvek alapvetően a sikeres, domináló és terjeszkedő államokról születnek, a dunai birodalom azonban egyértelműen nem ilyen volt. A könyv fő tétele az, hogy a Habsburgok megalkottak egy önálló, világos célokat és eszközöket használó geostratégiát, amely lehetővé tette e "gyenge" köztes területen fekvő állam túlélését.

Mitchell szerint a Habsburg-geostratégiát négy fő tényező határozta meg:

1. A geopolitikai környezet miatt a birodalom vezetőit a túlélés szüksége vezette. A koncepció ezért a túlélésre koncentráló, defenzív jellegű volt. Nem akartak felesleges területeket meghódítani, amelyek megtartásához nem lett volna erejük. 


\section{Külügyi Szemle}

2. Az állam gazdasági forrásainak a korlátozottsága miatt világosak voltak a hadsereg erejének a korlátai is. Ezért a Habsburgok a tárgyalást és a szövetségépítést legtöbbször fontosabbnak tartották, mint a nyílt háborút.

3. A defenzív stratégiában maximálisan figyelembe vették a földrajzi adottságot. Az osztrák erődök által dominált védelmi rendszer kiemelt része volt a nagystratégiának, amelynek a pufferzónák megerősítése, illetve határőr egységek telepítése is a részét képezte.

4. A stratégia fő eleme az idő volt. „Az időfaktor stratégiai befolyásolásával Ausztria jobbára sikeresen enyhítette a többfrontos háború nyomását a körkörös védelem teljes költségének megfizetése nélkül" (Mitchell, 2020, 31. o.). A többfrontos háborúk veszélye miatt kulcsfontosságú volt, hogy a szúkös erőforrásokat a kellő időben lehessen igénybe venni. A megfelelő földrajzi csomópontokba telepített erődök az ellenséges seregek lelassításával időt biztosítottak arra, hogy a szükséges erőket a veszélyeztetett helyre telepítsék.

Mitchell a munkájában egyetért a geopolitika azon megközelítésével, hogy egy állam mozgásterét alapvetően a földrajzi fekvése és a területe sajátosságai határozzák meg. Felhívja a figyelmet, hogy a Habsburg Birodalom belső szervezésének, kormányzásának az egyik alapeleme a területet egységbe fogó Duna. A folyó dominálta a birodalom közlekedését és gazdaságát. Mitchell szavaival: „Mindent egybevetve, a Duna nem pusztán segítette a Habsburg-területek politikai rendszerré kovácsolását és európai nagyhatalmi szerepvállalását, hanem egyenesen a folyó volt az, ami mindezt lehetóvé tette" (Mitchell, 2020, 47. 0.).

A szerző kiemeli továbbá, hogy a bécsi központú birodalom védelmi koncepciójának a központi részét jelentették a területén található hegyláncok. A földrajzi csomópontokban erődöket épített Ausztria. A földrajzi adottságokat figyelembe vevő erődépítés a Habsburgok geopolitikai gondolkodásának az egyik fő pillére volt. Mitchell elég világosan írja le a nagystratégiájuk földrajzi meghatározottságát: „A Habsburg-stratégia lelkét a sebezhetőség és védhetőség eme kombinációja alkotta. Ausztria geopolitikai környezete szükségesség tette a peremvidékek felöli támadások visszaverést célzó stratégiák kifejlesztését; földrajza és topográfiája pedig segítették a stratégia végrehajtását" (Mitchell, 2020, 71. 0.).

A szerző az Ausztria viszonylagos gyengeségéról szóló kezdeti tételét a kötetben sok bizonyítékkal támasztja alá. Az etnikai-nyelvi sokszínúség kimondottan akadályozta az állam egységesítését. Magyar szempontból például a korszak teljes egészében az uralkodói centralizációs törekvésekről és az ellenük fellépő magyar nemzeti ellenállásról szól. Szinte minden magyar (volt) diák, aki érettségizett történelemből, tudja, hogy II. József a halálos ágyán kényszerült visszavonni a centralizációs programját. Mitchell számára - aki szerint éppen a "kalapos király" által javasoltakhoz hasonló lépések 
vezettek volna el a birodalom megerősödéséhez - a magyar ellenállás "retrográd" jellegú volt, amely akadályozta a polgárosodást és a birodalom fejlődését.

A szerző jól ismeri fel, hogy a különböző történelmi hagyományokkal rendelkező területek egységes kormányzása szinte lehetetlen volt. A Habsburg Birodalom közigazgatása tulajdonképpen egymás melletti „szigetek" mozaikjaképpen épült fel: „A monarchiát alkotó területek inkább önálló szigetekből álló szigetcsoportokra hasonlítanak, mintsem egységes politikai entitásra; minden sziget külön megállapodást kötött a Habsburguralkodócsaláddal, amely lefektette a terület kötelezettségeit az uralkodó felé, valamint a felelősségeket és korlátozásokat az uralkodó számára" (Mitchell, 2020, 82. o.).

A dunai birodalom központosítását akadályozó tényezők elemzése után Mitchell részletesen kifejti a korábban tételszerúen leírt nagystratégia építőkockáit. A védekező, túlélésre tervezett stratégiát jól jelzi, hogy sokszor még győzedelmes háború végén sem akartak új területeket bekebelezni, mert azokat nem tudták volna megfelelően integrálni. Egy lázadásra hajlamos új terület annektálása ugyanis a gyakorlatban jelentős katonai erő ottani állomásoztatását vonta volna maga után. Az odaküldött egységek hiánya viszont tovább gyengítette volna a korántsem erős hadsereget egy komolyabb konfliktus esetén. A defenzív stratégia érdekes következménye volt, hogy hiába álltak többször is győzelemre a Habsburgok egy-egy háborúban, mégsem törekedtek a totális győzelemre: fontosabb volt a hadsereg integritásának a megőrzése, mint az esetleges területszerzés.

A hadsereg és az állam viszonylagos gyengeségének az ellensúlyozására az osztrákok maximálisan kihasználták a földrajzi lehetőségeiket. Nem véletlen, hogy talán éppen a dunai birodalomban készültek a legpontosabb katonai térképek. A terep tökéletes ismerete volt a Habsburg-stratégia egyik központi eleme, és abból olyan védelmi rendszert építettek ki, amelynek fő feladata az ellenséges alakulatok lelassítása volt. Az így nyert idő általában elégségesnek bizonyult az osztrák seregek átcsoportosítására. A geopolitikájuk másik újitását az irreguláris határőregységeknek a déli és a keleti határokra vezénylése jelentette. Így azok egyrészt lehetôvé tették a reguláris, jobban képzett csapatoknak a nyugati határra telepítését, másként fel lehetett használni őket a belső lázadók, főleg a magyarok ellen.

Az osztrák geostratégia fontos, talán a legfontosabb eleme az állandó szövetségépítési kényszer volt. A monarchia a relatív gyengeségét a szövetségi rendszerek felépítésével próbálta áthidalni. Mitchell szavaival: „A bécsi udvar harmadik eszköze a képességek és fenyegetések közötti úr áthidalására a koalíciós szerződések létrehozása volt, méghozzá olyan országokkal, amelyekkel meg tudta osztani a védelem terhét. A történelem során az állam földrajza nemcsak azt határozza meg, hogy mennyire van szüksége szövetségesekre, hanem azt is, milyen szövetségesekre van szüksége" (Mitchell, 2020, 126. о.). 


\section{Külügyi Szemle}

A nagyhatalmi szövetségek mellett fontos volt az ütközőzónákban elhelyezkedő kis államoké is. A bécsi katonai stratégák a tapasztalataik alapján nagyra értékelték az ilyen szövetségeket. A kisebb államok több kampányban hatékonyan lassították az osztrák területek felé igyekvő ellenséges nagy hatalmak seregeit.

Az osztrák geopolitikai gondolkodás aranykorát Klemens von Metternich idejére tehetjük. Akkoriban kodifikálódtak az európai szintú békerendszerben a Habsburg-stratégia legfontosabb normái. A Szent Szövetség Európájában az osztrák nagystratégia elemei a kontinentális erőegyensúly pilléreivé váltak. Mitchell szavai igen pontosan írják le az 1815 után létrejött „Pax Austriacát”:

„Az osztrákok a megnövekedett birtokaik védelmére és oltalmára a korábbi határvédelmi stratégiát olyan európai szintű biztonsági rendszerré fejlesztették, amely két pilléren nyugodott: az újjászervezett, megerősített ütközőzónák immár a szomszédos vidékeket integrálták; a kifinomult diplomáciai stratégiák pedig segítették a közvetítést konfliktusok idején, míg a pufferövezetek irányításába bevonták a versenytársakat is. (...) Az osztrák stratégiai vezetés csúcspontján e biztonsági rendszer a hegemón számos attribútumával ruházta fel a Monarchiát; s tette mindezt nemcsak a birodalom számára elfogadható áron, hanem olyan stabilitási feltételek létrehozásával, amelyek mintegy fél évszázadig kitartottak Európában" (Mitchell, 2020, 265. o.).

Bár a szerző részletesen kifejti a „Pax Austriaca” Solferino és Königgrätz utáni gyors összeomlását, a cikk korlátai miatt ennek részletes bemutatására itt nincs mód; annyi viszont megjegyezhető, hogy Mitchell szerint a vég kezdete az osztrák-magyar kiegyezés volt. Úgy véli, a Habsburg-ház az Ausgleich aláirásával tulajdonképpen feladta az egységes, központosított birodalom elvét. Nekünk, magyaroknak ez bizony mást jelentett... A könyv érdekes aspektusa magyar szempontból, hogy a szerző értékelésében a magyar függetlenedési törekvések, így a kiegyezéshez vezető folyamatok is visszalépést jelentettek, mivel azok akadályozták a centralizációra épító államreformot, amely nélkül a Habsburg Birodalom soha sem lett erős állam.

Összegzésként kijelenthető, hogy Mitchell könyve a történelem és a geopolitika szerelmesei számára egyaránt kitúnő olvasmány. A Habsburgok nagystratégiájának vizsgálata során a szerző igen sok érdekes tanulságot von le, amelyek a mai globális geopolitikai folyamatok értelmezéséhez is jól hasznosíthatóak. Az utóbbi időben megjelent két könyvével Mitchell fiatal kora ellenére az amerikai geopolitikai hagyomány nagyjai közé emelkedik.

Köszönet illeti az Antall József Tudásközpontot, amiért a szélesebb magyar közönség számára is elérhetővé váltak e fontos múvek. Egyetemi oktatóként szintén hasznosnak tartom a fordítást, hiszen egyelóre még a magyar doktori iskolákban sem jellemző az angol szakirodalom olvasása, nem is beszélve az angol nyelvú cikkek elismert folyóiratokban történő megjelentetése. 
Végezetül hadd idézzem Mitchellt a Habsburg-nagystratégia máig befolyással bíró hatásairól:

„Ausztria történetének tanulsága azt jelzi, hogy stabil nemzetközi rend egyben tartása sokkal inkább választás, semmint befolyásolhatatlan természeti erők eredménye. Ez kedvezőtlen színben tünteti fel azt a gondolatot, hogy egy nagyhatalomnak szükségképp bőséges erőforrásokkal kell rendelkeznie ahhoz, ha a környezetét hathatósan akarja manipulálni. (...) Ám mindenekelőtt a fő tanulság az, hogy az elszigetelődés a legnagyobb veszedelem, amely egy köztes országot fenyegethet. Még a legerősebb hatalomnak is szüksége van szövetségesekre, különösen tulajdon határai és a versenytársak területe között, hogy az időfaktort kézben tarthassa, hiszen attól függ mind a saját összetett helyzete, mind a rendszer stabilitása" (Mitchell, 2020, 379. o.).

\section{Irodalomjegyzék}

Grúber Károly

Grygiel, Jakub J. és Mitchell, A. Wess (2017). Nyugtalan határvidék. Felemelkedő riválisok, sebezhető szövetségesek és az amerikai hatalom válsága. Budapest: Antall József Tudásközpont.

Mitchell, A. Wess (2020). A Habsburg Birodalom nagystratégiája. Budapest: Antall József Tudásközpont.

Trump White House Archives (2017). National Security Strategy of the United States of America, December 2017. A letöltés ideje: 2021. január 26. https://trumpwhitehouse. archives.gov/wp-content/uploads/2017/12/NSS-Final-12-18-2017-0905-2.pdf. 